\title{
Physicochemical characteristics and antioxidant activities of green coffee bean extracted with different solvents
}

\author{
Ju-Hyeon Kim, Yul-Ri Gu, Joo-Heon Hong * \\ Department of Food Science and Technology, Catholic University of Daegu, Gyeongsan 38430, Korea
}

\section{추출용매에 따른 커피 생두 추출물의 이화학적 품질특성 및 항산화 활성}

\author{
김주현·구율리·홍주헌* \\ 대구가톨릭대학교 식품공학전공
}

\begin{abstract}
In this study, we aimed to examine the physicochemical characteristics and antioxidant activities of water (hot water extracts from Coffea canephora (HR), hot water extracts from Coffea arabica (HA)), $80 \%$ ethanol (80\% ethanol extracts from Coffea canephora (ER), 80\% ethanol extracts from Coffea arabica (EA)) and $80 \%$ methanol (80\% methanol extracts from Coffea canephora (MR), 80\% methanol extracts from Coffea arabica (MA)) of green coffee bean. The yield of green coffee bean extracts (HR, ER, MR, HA, EA, MA) was $15.53-23 \%$. The total sugar and protein contents of HA were $58.45 \mathrm{~g} / 100 \mathrm{~g}$ and $23.04 \mathrm{~g} / 100 \mathrm{~g}$, respectively. The total polyphenol and flavonoid contents of ER were $35.03 \mathrm{~g} / 100 \mathrm{~g}$ and $12.14 \mathrm{~g} / 100 \mathrm{~g}$, respectively. The main component in chlorogenic acid of green coffee bean extracts was 5-caffeoylquinic acid (5-CQA) (1.04-3.18 g/100 g). The DPPH and ABTS radical scavenging activities of $\mathrm{ER}$ at $1,000 \mu \mathrm{g} / \mathrm{mL}$ were $99.17 \%$ and $92.61 \%$, respectively. The superoxide radical scavenging and FRAP activities of ER at $1,000 \mu \mathrm{g} / \mathrm{mL}$ were $96.47 \%$ and $1572.23 \mu \mathrm{M}$, respectively. The protective effect of ER extract against oxidative stress was better than those of other extracts in L-132 cells $(85.82 \%)$. In conclusion, our study provides experimental evidence that green coffee bean extracts can be used as potential functional materials.
\end{abstract}

Key words : green coffea bean, Coffea Canephora, Coffea Arabica, antioxidant activities, L-132 cell

\section{서 론}

\section{산화적 스트레스의 직접적 원인이 되는 활성산소종} (reactive oxygen species, ROS)은 불안정하고 반응성이 높 아 여러 생체물질과 쉽게 반응하고(1), 체내고분자들을 공 격하여 세포와 조직에 비가역적인 손상을 일으켜 돌연변 이, 세포독성 및 발암 등을 초래한다(2). 이러한 활성산소종 에서 유발되는 각종 질환을 예방하기 위해서 항산화 물질을 충분히 섭취하는 것이 도움이 되며, 식물성 식품에 함유된

*Corresponding author. E-mail : jhhong@cu.ac.kr Phone : 82-53-850-3218, Fax : 82-53-850-3218

Received 13 September 2018; Revised 25 October 2018; Accepted 26 October 2018.

Copyright (c) The Korean Society of Food Preservation. All rights reserved.
페놀성 화합물은 항산화, 항염증, 항암 효과 등이 알려지면 서 기능성 소재로서 주목을 받고 있다(3).

커피는 꼭두서니과(Rubiaceae) 코페아속(Coffea)에 속하 고 아프리카의 에티오피아가 원산지로 현재는 아프리카, 남아메리카, 인도네시아, 베트남 등지에서 널리 재배되고 있으며(4), 쓴맛, 신맛, 떫은맛 및 고소한 맛 등의 특유한 맛과 향이 조화되어 만들어진 전세계 사람들이 즐겨마시는 대표적인 기호음료이다(5). 커피의 품종은 Coffea arabica (아라비카종), Coffea canephora(로부스타종) 및 Coffea liberica(리베리카종) 등 3 가지 품종으로 구분되며(6), 아라 비카 종과 로부스타종이 전 세계 산출량의 대부분을 차지하 고 있다(7). 커피 생두의 주요 성분은 생산지, 품종 및 재배 지역에 따라 약간의 차이는 있으나 일반적으로 수분 $10-13 \%$, 탄수화물 $37-60 \%$, 지방 9-18\%, 단백질 $11-13 \%$, 무기질 3.0-4.5\%, 카페인 0.9-2.4\%와 클로로겐산(chlorogenic 
acid) 5.5-10\%이다(4). 또한 커피 생두는 항산화 기능을 가 진 폴리페놀의 일종인 클로로겐산(chlorogenic acid)과 알 칼로이드의 일종인 카페인(caffeine) 및 트리고넬린 (trigonellien)을 포함하여 다양한 생리활성물질들을 포함하 고 있다(8). 커피에 대한 연구로는 커피의 배전 정도에 따른 분석(9), 커피의 종류에 따른 이화학적 성분 및 $\mathrm{GC}$ 에 의한 향기성분 분석(10), 추출수율에 관한 분석(11), 가용성 커피 에 관한 분석(12), 커피 보관 시 산패에 따른 향미 변화(13) 등 다양한 연구가 보고되어 있다. 또한 다양한 음료에서 페놀 화합물의 함량을 측정한 결과 레드와인보다 커피의 페놀 함량이 높은 것으로 나타났으며, 커피의 섭취가 LDL 의 산화에 대한 감수성을 줄임으로서 $\mathrm{LDL}$-콜레스테롤과 Malondialdehyde(MDA)를 줄인다는 보고가 있다(14). 이처 럼 커피 원두 관련 항산화 연구는 꾸준히 진행되고 있으나, 최근에 많이 소비되고 있는 커피 생두에 관한 연구는 부족 한 실정이다.

따라서 본 연구에서는 전 세계적으로 가장 많이 사용되 고 있는 로부스타 및 아라비카 커피 생두의 다양한 항산화 활성과 폐정상세포인 L-132 세포를 이용한 세포보호 효과 를 조사하여 커피 생두의 산업적 이용 증대 및 기능성 식품 소재로서의 활용 가능성을 조사하고자 하였다.

\section{재료 및 방법}

\section{실험재료}

본 실험에 사용된 커피 생두는 베트남산 로부스타(Coffea canephora) 및 아라비카(Coffea arabica)종으로 경상북도 문경시 소재 (주)루왁코리아로 부터 제공받아 사용하였다. 커피 생두를 자연 건조하여 수분함량이 $10 \%$ 이하가 되도록 한 후 분쇄기(RT-04, Hanil Co., Sejong, Korea)로 분쇄하여 $60 \mathrm{mesh}$ 를 통과한 분말을 $-70^{\circ} \mathrm{C}$ 이하의 암소에 보관하면서 추출용 시료로 사용하였다.

\section{추출물의 제조}

커피 생두 추출물은 생두 분말 $30 \mathrm{~g}$ 에 10 배의 증류수, $80 \%$ 에탄올 및 $80 \%$ 메탄올을 첨가하여 $100^{\circ} \mathrm{C}$ 및 $80^{\circ} \mathrm{C}$ 에서 4시간 동안 환류냉각추출기(CA-1112, Eyela Co., Tokyo, Japan)를 이용하여 추출하였고 각각의 추출물은 불순물을 제거하기 위하여 여과지(No.2, Whatman Intermational Ltd., Leicestershire, England)를 이용하여 여과하였다. 여과된 추 출물은 감압농축기(Model N-1N, Eyela Co., Tokyo, Japan) 로 농축한 다음, 동결건조기(Free Zone 2.5, Labconco Co., $\mathrm{Kansas}, \mathrm{MO}, \mathrm{USA}$ )로 건조하여 $-70^{\circ} \mathrm{C}$ 이하의 암소에서 보관 하면서 분석용 시료로 사용하였다.

\section{추출수율, 총 당 및 가용성 단백질 함량}

추출수율은 추출물을 동결건조한 다음 건물 중량을 구하 였고 추출물 제조에 사용한 원료 건물량에 대한 백분율로 나타내었다.

총 당 함량 분석은 Saha와 Brewer(15)의 방법에 따라 phenol-sulfuric acid법으로 분석하였다. $1 \mathrm{~mL} 5 \%$ phenol 과 $5 \mathrm{~mL}$ sulfuric acid를 $1 \mathrm{~mL}$ 시료와 반응시킨 후 분광광도 계(Ultraspec 2100 pro, Biochrom Ltd., Uppsala, Sweden)를 사용하여 $525 \mathrm{~nm}$ 에서 흡광도를 측정하고 glucose(SigmaAldrich Co., St. Louis, MO, USA)를 이용하여 작성한 표준 곡선으로부터 계산하였다.

가용성 단백질 함량은 Lowry 등(16)의 방법으로 측정하 였으며 bovine serum albumin(BSA, Sigma-Aldrich Co.)을 이용하여 작성한 표준곡선으로부터 계산하였다.

\section{총 폴리페놀 및 총 플라보노이드 함량}

총 폴리페놀 함량은 Folin-Denis법(17)에 따라 $1 \mathrm{~mL}$ 시료 에 $1 \mathrm{~mL} 1 \mathrm{~N}$ Folin Ciocalteu reagent를 첨가하고 충분히 혼합한 다음, $1 \mathrm{~mL} 20 \% \mathrm{Na}_{2} \mathrm{CO}_{3}$ 를 첨가하여 실온의 암소에 서 30 분간 반응시킨 후 분광광도계(Ultrospec 2100 pro, Biochrom Ltd.)를 이용하여 $725 \mathrm{~nm}$ 에서 흡광도를 측정하였 다. 총 폴리페놀 함량은 gallic acid(Sigma-Aldrich Co.)를 이용하여 작성한 표준곡선으로부터 계산하였다.

총 플라보노이드 함량은 Jia 등(18)의 방법을 응용하여 측정하였다. $1 \mathrm{~mL}$ 시료에 $150 \mu \mathrm{L} 5 \% \mathrm{NaNO}_{2}$ 를 혼합하여 실온에서 6분간 반응시킨 다음 $300 \mu \mathrm{L} 10 \% \mathrm{AlCl}_{3}$ 과 혼합하 여 다시 실온에서 5 분간 반응시킨 후, $1 \mathrm{~mL} 1 \mathrm{~N} \mathrm{NaOH}$ 와 혼합하여 분광광도계(Ultrospec 2100 pro, Biochrom Ltd.)를 이용하여 $510 \mathrm{~nm}$ 에서 흡광도를 측정하였다. 총 플라보노이 드함량은 rutin(Sigma-Aldrich Co.)을 이용하여 작성한 표준 곡선으로부터 계산하였다.

\section{Chlorogenic acid 함량 분석}

커피 생두 추출물의 chlorogenic acid 함량은 Kintex $\mathrm{C}_{18}$ column $(5 \mu \mathrm{m}, 4.6 \mathrm{~mm} \times 100 \mathrm{~mm}$, Phenomenex Co.)이 부착된 Alliance HPLC system(Waters 2695, Waters Co., Milford, $\mathrm{MA}, \mathrm{USA})$ 을 이용하여 분석하였다. 컬럼의 온도는 $45^{\circ} \mathrm{C}$ 로 조절하였고, 검출기는 photodiode array detector(Waters 2996, Waters Co.)를 사용하였다. 이동상은 Water: Trifluoroacetic acid(99.9:0.1, v/v)와 100\% acetonitrile로 유 속은 $1.5 \mathrm{~mL} / \mathrm{min}$, 시료주입량은 $3 \mu \mathrm{L}$ 로 분석하였다. Chlorogenic acid의 표준물질(Fig. 1)은 3-caffeoylquinic acid, 4-caffeoylquinic acid, 5-caffeoylquinic acid, 4,5-dicaffeoylquinic acid, 3,4-dicaffeoylquinic acid 및 3,5-dicaffeoylquinic acid 6종을 Sigma-Aldrich Co.로부터 구입하여 사용하였고, 시료 에 함유된 chlorogenic acid의 함량은 표준물질의 머무름 시간을 비교하여 분석하였다. 

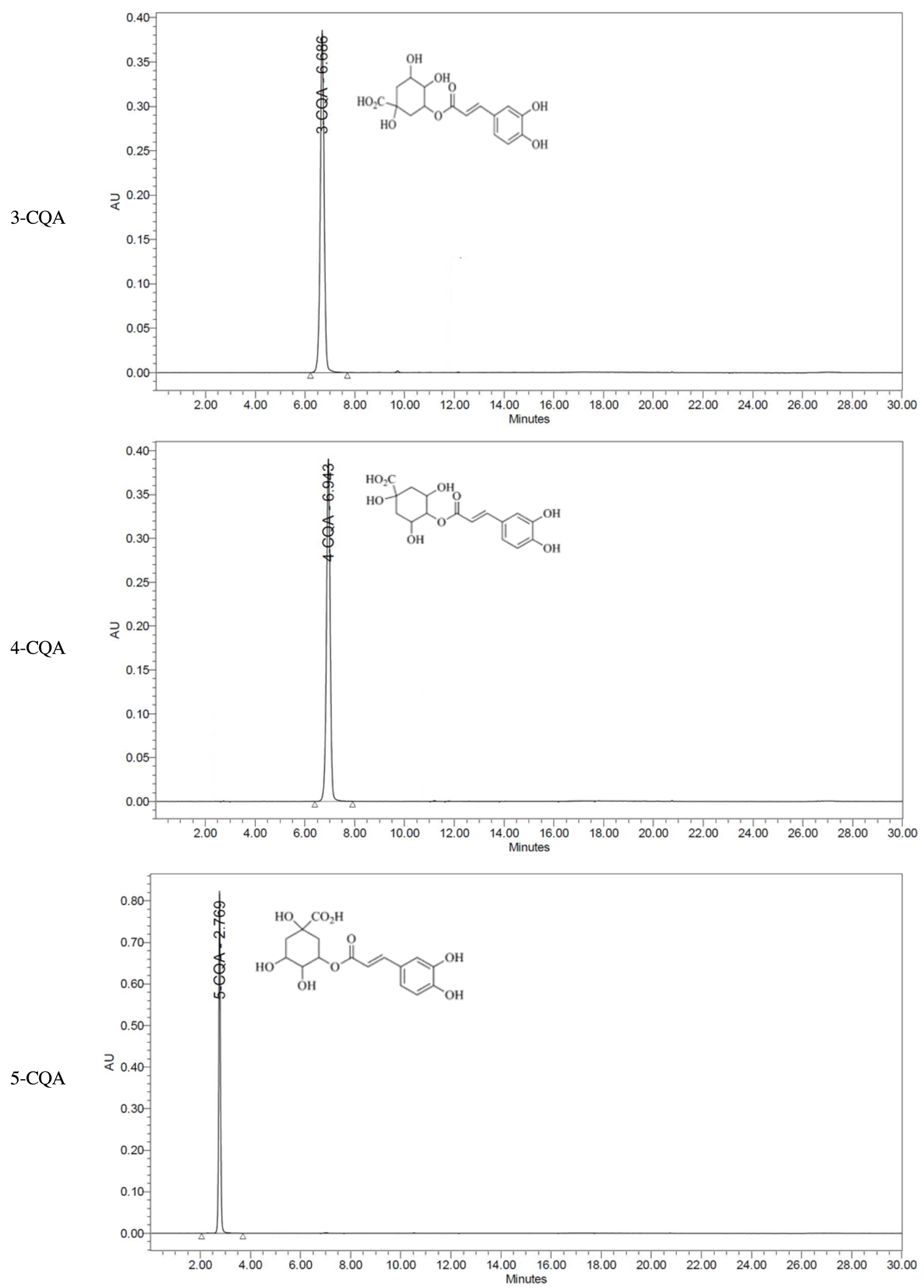

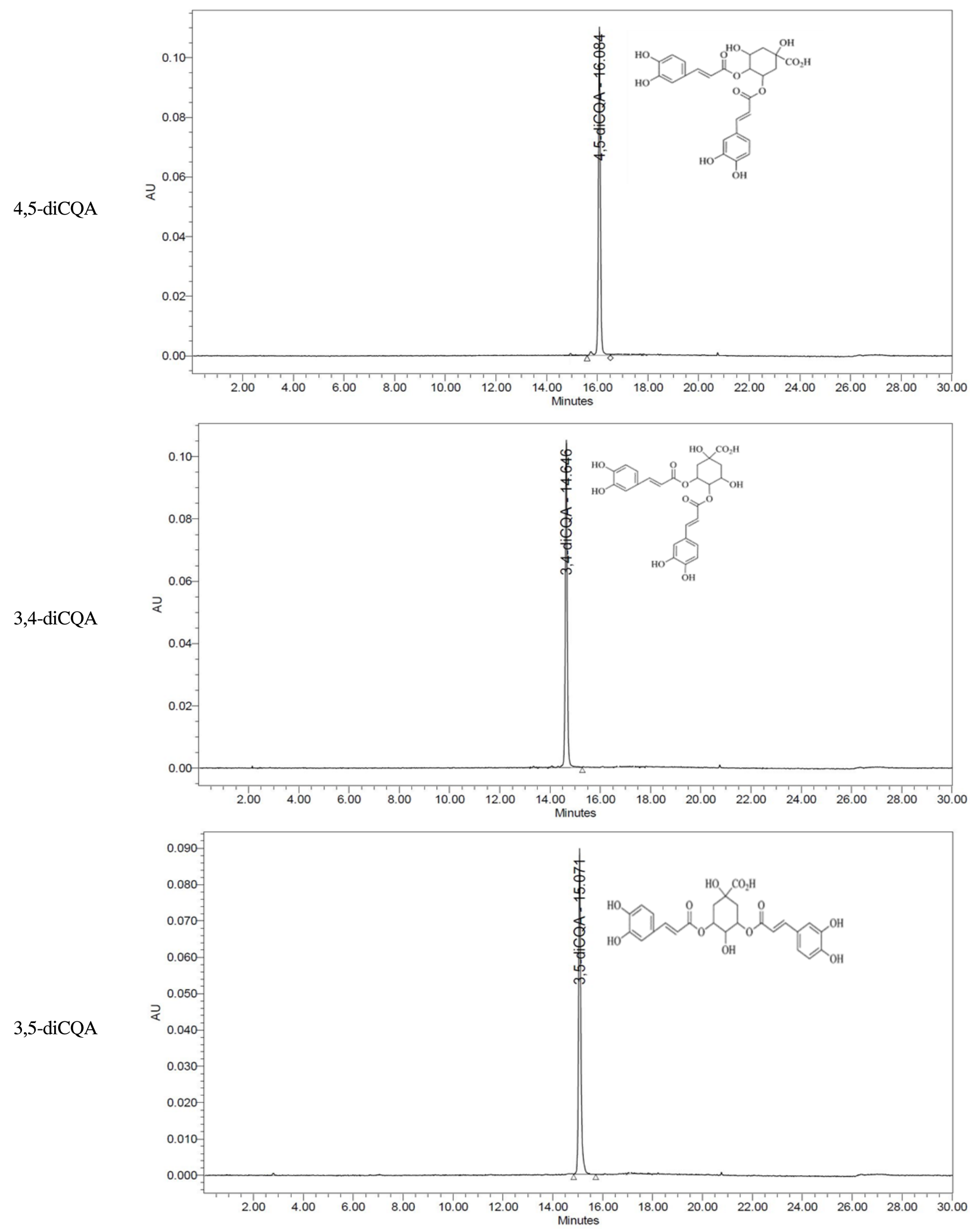

Fig. 1. Chemical structures and chromatogram of major chlorogenic acids present in green coffee bean extract.

3-CQA, 3-caffeoylquinic acid; 4-CQA, 4-caffeoylquinic acid; 5-CQA, 5-caffeoylquinic acid, 4,5-diCQA, 4,5-dicaffeoylquinic acid; 3,4-diCQA, 3,4-dicaffeoylquinic acid; 3,5-diCQA, 3,5-dicaffeoylquinic acid. 


\section{$\mathrm{DPPH}$ radical 소거활성 측정}

DPPH radical 소거활성은 1,1-diphenyl-2-pycrylhydrazyl (DPPH, Sigma-Aldrich Co.)의 환원력을 이용하여 측정하였 다(19). DPPH reagent는 $12 \mathrm{mg}$ DPPH를 $100 \mathrm{~mL}$ absolute ethanol에 용해한 후 $100 \mathrm{~mL}$ 증류수를 첨가하여 흡광도를 $517 \mathrm{~nm}$ 에서 약 1.5 로 조정하여 제조하였다. $0.5 \mathrm{~mL}$ 시료에 $5 \mathrm{~mL}$ DPPH reagent를 혼합하여 실온에서 15 분간 반응시킨 후 분광광도계(Ultrospec 2100pro, Biochrom Ltd.)로 흡광도 를 측정하고 아래와 같이 계산하였다.

$$
\text { DPPH radical scavenging activity }(\%)=\left(1-\frac{\mathrm{S}}{\mathrm{C}}\right) \times 100
$$

S : absorbance of sample at $517 \mathrm{~nm}$

C : absorbance of control at $517 \mathrm{~nm}$

\section{ABTS radical 소거활성 측정}

2,2'-Azino-bis(3-ethylbenzothiazoline-6-sulfonic acid (ABTS) radical 소거활성(20)은 $7.4 \mathrm{mM} \mathrm{ABTS(Sigma-}$ Aldrich Co.)와 $2.45 \mathrm{mM}$ potassium persulfate를 최종 농도로 혼합하여 실온인 암소에서 24시간 동안 방치하여 $\mathrm{ABTS}^{+}$을 형성시킨 후 $732 \mathrm{~nm}$ 에서 흡광도 값이 $0.70 \pm 0.02$ 가 되게 phosphate buffer saline(PBS, pH 7.4)으로 희석하였다. 희석 된 용액 $180 \mu \mathrm{L}$ 에 시료 $20 \mu \mathrm{L}$ 를 혼합하여 1 분간 반응시킨 다음 분광광도계(Ultraspec 2100pro, Biochrom Ltd.)를 이용 하여 $732 \mathrm{~nm}$ 에서 흡광도를 측정하였다. ABTS radical 소거 활성은 시료의 첨가 전과 후의 차이를 아래와 같이 백분율 로 나타내었다.

$$
\begin{aligned}
& \text { ABTS radical scavenging activity }(\%)=\left(1-\frac{\mathrm{S}}{\mathrm{C}}\right) \times 100 \\
& \mathrm{~S}: \text { absorbance of sample at } 732 \mathrm{~nm} \\
& \mathrm{C}: \text { absorbance of control at } 732 \mathrm{~nm}
\end{aligned}
$$

\section{Superoxide radical 소거활성 측정}

Superoxide radical 소거활성은 Nishikimi 등(21)의 방법에 따라 다음과 같이 측정하였다. 시료 $500 \mu \mathrm{L}$ 에 $100 \mu \mathrm{L} 0.1$ $\mathrm{M}$ Tris-HCl 완충용액(pH 8.5) 및 $200 \mu \mathrm{L} 100 \mu \mathrm{M}$ phenazine methosulfate(PMS, Sigma-Aldrich Co.)를 혼합하여 반응 시 킨 후, $500 \mu \mathrm{M}$ nitro blue tetrazolium(NBT, Sigma- Aldrich Co.) $200 \mu \mathrm{L}$ 및 $400 \mu \mathrm{L} 500 \mu \mathrm{M} \beta$-nicotinamide adenine dinucleotide(NADH, Sigma-Aldrich Co.)를 첨가하여 실온 에서 10 분간 반응시킨 다음 분광광도계(Ultraspec 2100 pro, Biochrom Ltd.)를 이용하여 $560 \mathrm{~nm}$ 에서 흡광도를 측정하였 다. Superoxide radical 소거활성은 시료의 첨가 전과 후의 차이를 아래와 같이 백분율로 나타내었다.

Superoxide radical scavenging activity $(\%)=\left(1-\frac{S}{C}\right) \times 100$
S : absorbance of sample at $560 \mathrm{~nm}$

C : absorbance of control at $560 \mathrm{~nm}$

Ferric reducing antioxidant power(FRAP) 측정

FRAP는 Benzie와 Strain의 방법(22)에 따라 다음과 같이 측정하였다. FRAP reagent는 $25 \mathrm{~mL}$ acetate buffer $(300 \mathrm{mM}$, $\mathrm{pH}$ 3.6)를 $37^{\circ} \mathrm{C}$ 에서 가온한 후, $40 \mathrm{mM} \mathrm{HCl}$ 에 용해한 10 $\mathrm{mM}$ 2,4,6-tris(2-pyridyl)-s-triazine(TPTZ, Sigma-Aldrich Co.) $2.5 \mathrm{~mL}$ 와 $20 \mathrm{mM}$ ferric chloride( $\left(\mathrm{FeCl}_{3}\right) 2.5 \mathrm{~mL}$ 를 첨가하 여 제조하였다. 시료 $30 \mu \mathrm{L}$ 에 제조된 FRAP reagent 900 $\mu \mathrm{L}$ 와 증류수 $90 \mu \mathrm{L}$ 를 넣은 후, $37^{\circ} \mathrm{C}$ 에서 10 분간 반응시켜 분광광도계(Ultraspec 2100pro, Biochrom Ltd.)를 이용하여 $510 \mathrm{~nm}$ 에서 흡광도를 측정하였다. $\mathrm{FRAP}$ 는 $\mathrm{FeSO}_{4} \cdot 7 \mathrm{H}_{2} \mathrm{O}$ (Sigma-Aldrich Co.)을 이용하여 작성한 표준곡선으로부터 계산하였다.

\section{세포배양}

실험에 사용한 인간 폐상피세포주인 L-132 세포는 한국 세포주은행(KTCC, Seoul, Korea)에서 분양받아 사용하였 다. 세포배양은 Dulbecco's modified eagle's medium (DMEM) (Welgene, Daegu, Korea)를 이용하여 각각 10\% fetal bovine serum(Gibco BRL Co., Grand Island, NY, USA) 및 $1 \%$ penicillin streptomycin(Gibco BRL Co.)을 첨가하여 배양하였다. 세포는 $37^{\circ} \mathrm{C}, 5 \% \mathrm{CO}_{2}$ incubator (MCO-18AIC, Sanyo Co., Osaka, Japan)에서 배양하였다.

\section{세포독성}

세 포독성은 3-(4,5-dimethylthiazol-2-yl)-2,5-diphenyltet -razolium bromide(MTT) assay로 측정하였다. 배양된 세포 주를 $1 \times 10^{4} \mathrm{cell} / \mathrm{well}$ 의 농도로 96-well plate에 $100 \mu \mathrm{L}$ 씩 첨가하여 24시간 배양하고, 이후 새로운 배지에 시료를 농 도별로 처리한 다음 24시간 동안 배양하였다. 배양 후 PBS 완충용액에 녹인 MTT $(5 \mathrm{mg} / \mathrm{mL}$, Sigma-Aldrich Co.) 용액 을 각 well에 $10 \mu \mathrm{L}$ 씩 첨가하고 다시 4시간 동안 배양하여 MTT가 환원되도록 하였다. 이후 상등액을 완전히 제거하 고 dimethyl sulfoxide(DMSO, Jensei Chemical Co., Tokyo, Japan) $100 \mu \mathrm{L}$ 를 각 well에 첨가한 후, 10 분간 반응시켜 formazan 결정을 완전히 용해한 다음 microplate reader(UVM-340, Asys Co., Biochrom, Cambridge, UK)를 이용하여 $540 \mathrm{~nm}$ 에서 흡광도를 측정하였다.

\section{산화적 손상에 대한 세포보호 효과}

L-132 세포를 이용한 세포보호 효과는 Hwang(23)의 방 법을 응용하여 측정하였다. 배양된 L-132 세포를 $1 \times 10^{4}$ cell/well의 농도로 96-well plate에 $100 \mu \mathrm{L}$ 씩 첨가하여 24시 간 배양하고, 이후 새로운 배지로 교환한 다음 $1 \mathrm{mM}$ $\mathrm{H}_{2} \mathrm{O}_{2}$ (Duksan pure chemicals Co., Ltd., Ansan, Korea) 및 
시료를 농도별로 처리하여 12시간 동안 배양하였다. 배양 완료 후, PBS 완충용액에 녹인 $\mathrm{MTT}(5 \mathrm{mg} / \mathrm{mL}$, SigmaAldrich Co.) 용액을 각 well에 $10 \mu \mathrm{L}$ 씩 첨가하고 4시간 동안 배양하여 MTT가 환원되도록 하였다. 이후 상등액을 완전히 제거하고 DMSO(Junsei Chemical Co.) $100 \mu \mathrm{L}$ 를 각 well에 첨가한 후, 10 분간 반응시켜 formazan 결정을 완전히 용해한 다음 microplate reader(UVM-340, Asys Co.)를 이용 하여 $540 \mathrm{~nm}$ 에서 흡광도를 측정하였다.

\section{통계처리}

모든 실험결과는 SPSS(19.0, SPSS Inc., Chicago, IL, $\mathrm{USA}$ )를 이용한 분산분석(ANOVA)을 실시하였고 각 측정 평균값의 유의성 $(\mathrm{p}<0.05)$ 은 Duncan's multiple range test를 실시하여 검정하였다.

\section{결과 및 고찰}

\section{추출수율, 총 당 및 가용성 단백질 함량}

커피 생두 추출물의 추출수율, 총 당 및 가용성 단백질 함량은 Table 1 과 같다. 추출용매에 따른 추출수율은 로부 스타 및 아라비카 커피 생두가 열수추출물에서 각각 $20.2 \%$ 및 $23 \%$ 로 가장 높았으며, $80 \%$ 메탄올 추출물에서 각각 $15.53 \%$ 및 $16.2 \%$ 로 가장 낮게 나타났다. Han 등(24)은 추출 용매에 따른 무순 추출물의 추출수율을 측정한 결과 물, 에탄올 및 메탄올 순으로 나타났다고 보고하여 본 연구의 결과와 유사하였으며, Kwon 등(25)은 추출용매의 극성이 증가할수록 식물체에 존재하는 수용성 폴리페놀 화합물과 방향족 아민 등의 용출이 증가하여 극성용매에서의 추출수 율이 높게 나타난 것이라고 보고하였다. 총 당 함량은 각각 의 추출물에서 유의적인 차이를 나타내었는데, 로부스타 및 아라비카 커피 생두 모두 열수추출물에서 각각 50.17 $\mathrm{g} / 100 \mathrm{~g}$ 및 $58.45 \mathrm{~g} / 100 \mathrm{~g}$ 으로 가장 높은 함량을 나타내었으

Table 1. Yield, total sugar and soluble protein contents of green coffee bean extracts

\begin{tabular}{cccc}
\hline Sample $^{1)}$ & $\begin{array}{c}\text { Yield } \\
(\%)\end{array}$ & $\begin{array}{c}\text { Total sugar } \\
(\mathrm{g} / 100 \mathrm{~g})\end{array}$ & $\begin{array}{c}\text { Soluble protein } \\
(\mathrm{g} / 100 \mathrm{~g})\end{array}$ \\
\hline HR & $20.20 \pm 0.02^{\mathrm{c} 2}$ & $50.17 \pm 0.58^{\mathrm{b}}$ & $21.26 \pm 0.65^{\mathrm{b}}$ \\
ER & $19.60 \pm 0.05^{\mathrm{d}}$ & $38.58 \pm 0.12^{\mathrm{e}}$ & $11.37 \pm 0.07^{\mathrm{e}}$ \\
MR & $15.53 \pm 0.09^{\mathrm{f}}$ & $44.67 \pm 0.35^{\mathrm{d}}$ & $17.90 \pm 0.45^{\mathrm{c}}$ \\
\hline HA & $23.00 \pm 0.13^{\mathrm{a}}$ & $58.45 \pm 0.36^{\mathrm{a}}$ & $23.04 \pm 0.36^{\mathrm{a}}$ \\
EA & $20.47 \pm 0.06^{\mathrm{b}}$ & $44.84 \pm 0.61^{\mathrm{d}}$ & $15.75 \pm 0.62^{\mathrm{d}}$ \\
MA & $16.20 \pm 0.03^{\mathrm{e}}$ & $48.64 \pm 0.36^{\mathrm{c}}$ & $17.55 \pm 1.19^{\mathrm{c}}$ \\
\hline
\end{tabular}

${ }^{1)} \mathrm{HR}$, hot water extracts from Coffea Canephora, ER, 80\% ethanol extracts from Coffea Canephora; MR, 80\% methanol extracts from Coffea Canephora, HA, hot water extracts from Coffea Arabica, EA, 80\% ethanol extracts from Coffea Arabica; MA, $80 \%$ methanol extracts from Coffea Arabica.

${ }^{2)}$ Different superscripts within a column $(\mathrm{a}-\mathrm{f})$ indicate significant differences $(\mathrm{p}<0.05)$.
며, $80 \%$ 에탄올 추출물에서 각각 $38.58 \mathrm{~g} / 100 \mathrm{~g}$ 및 44.84 $\mathrm{g} / 100 \mathrm{~g}$ 으로 가장 낮았다. $\mathrm{Kim}$ 과 $\operatorname{Han}(14)$ 은 커피의 생산지, 품종, 재배 등에 따라 약간의 차이는 있으나 일반적으로 커피 생두에는 약 37-60\%의 당이 함유되어 있다고 보고하 여 본 연구의 결과와 유사하였다. 가용성 단백질 함량은 로부스타 및 아라비카 커피 생두 열수추출물에서 각각 $21.26 \mathrm{~g} / 100 \mathrm{~g}$ 및 $23.04 \mathrm{~g} / 100 \mathrm{~g}$ 으로 가장 많이 함유되어 있었으며 $80 \%$ 에탄올 추출물에서 가장 낮은 함량을 나타내 총 당 함량과 유사한 경향을 나타내었다. $\operatorname{Kim}(26)$ 은 두부, 두유, 비지 등 여러 대두 식품들의 가용성 단백질 함량을 분석한 결과 두유에서 $204.8 \mathrm{mg} / \mathrm{g}$ 으로 가장 높았다고 보고 하였다.

\section{총 폴리페놀 및 총 플라보노이드 함량}

폴리페놀 화합물은 식물계에 널리 분포되어 있는 2 차 대사 산물의 하나로 ROS에 의한 세포 수준이나 DNA 등의 손상을 억제하기 위한 방어 메커니즘을 제공한다고 알려져 있다(27). 커피 생두 추출물의 총 폴리페놀 및 총 플라보노 이드 함량은 Table 2와 같다. 총 폴리페놀 함량은 20.37$35.03 \mathrm{~g} / 100 \mathrm{~g}$ 으로 추출용매 및 커피 품종에 따라 유의적인 차이를 나타내었으며, 로부스타 및 아라비카 커피 생두 $80 \%$ 에탄올 추출물이 각각 $35.03 \mathrm{~g} / 100 \mathrm{~g}$ 및 $29.38 \mathrm{~g} / 100$ $\mathrm{g}$ 으로 다른 용매 추출물에 비해 페놀성물질의 함량이 높은 것을 확인하였다. 총 플라보노이드 함량은 로부스타 및 아 라비카 커피 생두 $80 \%$ 에탄올 추출물에서 각각 $12.14 \mathrm{~g} / 100$ $\mathrm{g}$ 및 $8.20 \mathrm{~g} / 100 \mathrm{~g}$ 으로 가장 많이 함유되어 있었으며, $80 \%$ 메탄올 및 열수추출물 순으로 높은 함량을 나타내었다. Cho 등(28)은 현재 시판되고 있는 커피에 함유된 폴리페놀 함량 을 측정한 결과 $18.88-43.90 \mathrm{mg} / \mathrm{mL}$ 로 보고하였으며, Park과 $\operatorname{Hong}(29)$ 은 추출방법에 따른 상지추출물의 폴리페놀 함량 을 분석한 결과, $50 \%$ 에탄올로 추출하였을 때 가장 높은 함량을 나타내어 본 연구 결과와 유사하였다. 이는 물과 유기용매가 혼합되어있어 시료에 함유되어 있는 페놀성물

Table 2. Total phenolic and total flavonoid contents of green coffee bean extracts

\begin{tabular}{ccc}
\hline Sample $^{1)}$ & $\begin{array}{c}\text { Total phenolic } \\
(\mathrm{g} / 100 \mathrm{~g})\end{array}$ & $\begin{array}{c}\text { Total flavonoid } \\
(\mathrm{g} / 100 \mathrm{~g})\end{array}$ \\
\hline HR & $28.46 \pm 0.08^{\mathrm{c} 2)}$ & $8.19 \pm 0.10^{\mathrm{c}}$ \\
ER & $35.03 \pm 0.11^{\mathrm{a}}$ & $12.14 \pm 0.23^{\mathrm{a}}$ \\
MR & $29.48 \pm 0.04^{\mathrm{b}}$ & $9.33 \pm 0.15^{\mathrm{b}}$ \\
\hline HA & $20.37 \pm 0.07^{\mathrm{e}}$ & $4.88 \pm 0.17^{\mathrm{e}}$ \\
EA & $29.38 \pm 0.12^{\mathrm{b}}$ & $8.20 \pm 0.35^{\mathrm{c}}$ \\
MA & $24.40 \pm 0.08^{\mathrm{d}}$ & $7.44 \pm 0.17^{\mathrm{d}}$ \\
\hline
\end{tabular}

${ }^{13} \mathrm{HR}$, hot water extracts from Coffea Canephora, ER, 80\% ethanol extracts from Coffea Canephora; MR, 80\% methanol extracts from Coffea Canephora; HA, hot water extracts from Coffea Arabica; EA, 80\% ethanol extracts from Coffea Arabica; MA, $80 \%$ methanol extracts from Coffea Arabica.

${ }^{2)}$ Different superscripts within a column $(\mathrm{a}-\mathrm{e})$ indicate significant differences $(\mathrm{p}<0.05)$. 
질의 용출이 용이하기 때문이라고 보고하였다.

\section{Chlorogenic acid(CGA) 함량}

Chlorogenic acid(CGA)는 quinic acid에 caffeic acid가 에 스테르 결합을 하고 있으며, caffeoylquinic acid(CQA), dicaffeoylquinic acid(diCQA) 및 feruloylquinic acid(FQA) 등 3 개의 이성질체를 가지고 있다(30). 또한 배전공정 중 화학적으로 쉽게 분해되어 여러종류의 페놀화합물을 생성 하며 이러한 페놀화합물은 커피의 맛과 향에 많은 영향을 주기 때문에 커피의 품질을 평가하는 중요한 성분으로 알려 져 있다(31). 커피 생두 추출물의 CGA 함량을 측정한 결과 는 Table 3과 같다. CGA 함량은 로부스타 커피 생두 $80 \%$ 에탄올 추출물이 가장 많이 함유하고 있었으며, 두 품종 모두 $80 \%$ 에탄올, $80 \%$ 메탄올 및 열수추출물 순으로 높은 $\mathrm{CGA}$ 함량을 나타내었다. 각 추출물의 $\mathrm{CGA}$ 함량은 5-caffeoylquinic acid(5-CQA), 3-caffeoylquinic acid(3-CQA), 4-caffeoylquinic acid(4-CQA), 3,4-dicaffeoylquinic acid(3,4diCQA), 4,5-dicaffeoylquinic acid(4,5-diCQA) 및 3,5dicaffeoylquinic $\operatorname{acid}(3,5-\mathrm{diCQA})$ 순으로 나타났으며, 5-CQA는 CGA의 주된 형태로 전체 $\mathrm{CGA}$ 중 약 $36-42 \%$ 를 차지한다고 알려져 있는데(32), 본 연구에서도 모든 추출물 에서 5-CQA가 1.04-3.18 g/100 g으로 가장 높은 함량을 나 타내었다. Farah와 Donangelo(33)는 CGA는 항산화작용을 비롯하여 간 보호효과, 혈당강하, 항바이러스 효과 등의 다양한 생리기능성을 가진다고 보고하였으며, $\operatorname{Park(34)ㅇㅡㄴ~}$ 벤젠 고리에 hydroxyl 라디칼이 결합된 CQAs가 다른 CGA 유도체보다 우수한 항산화 활성을 나타냈다고 보고하여 $\mathrm{CQAs}$ 의 함량이 가장 높았던 로부스타 커피 생두 $80 \%$ 에탄 올 추출물에서 항산화 활성이 우수할 것으로 사료된다.

\section{$\mathrm{DPPH}$ 및 ABTS radical 소거활성}

커피 생두 추출물의 DPPH 및 ABTS radical 소거활성은 Fig. 2와 같다. DPPH radical 소거활성(Fig. 2A)은 모든 시료
에서 농도 의존적으로 증가하였으며, 로부스타 및 아라비 카 커피 생두 $80 \%$ 에탄올 추출물이 $1,000 \mu \mathrm{g} / \mathrm{mL}$ 농도에서 각각 $99.17 \%$ 및 $91.26 \%$ 로 다른 용매 추출물보다 우수한 활성을 나타내었고, 로부스타 커피 생두 추출물이 아라비 카 커피 생두 추출물보다 높은 활성을 나타내었다. $\operatorname{Kim}(35)$ 은 커피 품종별 원두 열수추출물의 DPPH radical 소거활성 을 조사한 결과, $4 \mathrm{mg} / \mathrm{mL}$ 농도에서 약 $84-87 \%$ 의 소거활성 을 나타낸다고 보고해 커피 생두 추출물이 커피 원두 추출 물보다 DPPH radical 소거활성이 높음을 확인하였고, Park(34)은 3-CQA, 4-CQA, 5-CQA의 DPPH radical 소거활 성은 유도체별로 유의적인 차이를 나타내지 않아 CGA 구 조 내의 에스테르 결합 위치가 활성에 큰 영향을 미치지 않는다고 보고하였다. ABTS radical 소거활성(Fig. 2B)은 $80 \%$ 에탄올 추출물이 $12.85-92.61 \%$ 로 가장 높게 나타났으 며, 로부스타 커피 생두 추출물이 $100-1,000 \mu \mathrm{g} / \mathrm{mL}$ 농도에 서 16.91-92.61\%로 아라비카 커피 생두 추출물보다 우수한 항산화 활성을 나타내 DPPH radical 소거활성과 유사한 경향을 나타내었다. Woo(36)의 연구에서 커피 품종별 ABTS radical 소거활성을 조사한 결과, $1,000 \mu \mathrm{g} / \mathrm{mL}$ 농도에 서 약 $90 \%$ 이상의 소거활성을 보여 본 연구의 결과와 유사 하였다. 총 폴리페놀 및 총 플라보노이드 함량이 높게 나타 난 로부스타 커피 생두 $80 \%$ 에탄올 추출물이 $\mathrm{DPPH}$ 및 ABTS radical 소거활성에서도 높은 활성을 나타내었는데, 이는 페놀성 화합물의 함량이 커피의 항산화력과 밀접한 관련을 보인다고 보고한 Lee 등(37)의 결과와 유사하였다.

\section{Superoxide radical 소거활성 및 FRAP 활성}

커피 생두 추출물의 superoxide radical 소거활성 및 FRAP 활성은 Fig. 3과 같다. Superoxide radical 소거활성(Fig. 3A) 은 로부스타 및 아라비카 커피 생두 $80 \%$ 에탄올 추출물이 $1,000 \mu \mathrm{g} / \mathrm{mL}$ 농도에서 $96.47 \%$ 및 $86.60 \%$ 로 가장 높은 활성 을 나타내었으며, $80 \%$ 메탄올 및 열수추출물 순으로 활성 이 높았다. FRAP 활성(Fig. 3B)은 모든 시료에서 농도 의존

Table 3. Chlorogenic acid contents of green coffee bean extracts

\begin{tabular}{ccccccc}
\hline \multirow{2}{*}{ Sample $^{1)}$} & \multicolumn{5}{c}{ Chlorogenic acid (g/100 g) } \\
\cline { 2 - 7 } & $3-\mathrm{CQA}^{2)}$ & $4-\mathrm{CQA}$ & 5 -CQA & 4,5 -diCQA & 3,4-diCQA & 3,5 -diCQA \\
\hline HR & $1.00 \pm 0.02^{\mathrm{d} 3)}$ & $0.93 \pm 0.14^{\mathrm{b}}$ & $1.18 \pm 0.05^{\mathrm{d}}$ & $0.40 \pm 0.06^{\mathrm{b}}$ & $0.64 \pm 0.11^{\mathrm{b}}$ & $0.14 \pm 0.06^{\mathrm{c}}$ \\
ER & $2.14 \pm 0.11^{\mathrm{a}}$ & $1.39 \pm 0.40^{\mathrm{a}}$ & $3.18 \pm 0.15^{\mathrm{a}}$ & $0.37 \pm 0.04^{\mathrm{b}}$ & $0.62 \pm 0.05^{\mathrm{b}}$ & $0.21 \pm 0.05^{\mathrm{bc}}$ \\
MR & $1.25 \pm 0.03^{\mathrm{c}}$ & $1.00 \pm 0.27^{\mathrm{ab}}$ & $1.57 \pm 0.02^{\mathrm{c}}$ & $0.84 \pm 0.03^{\mathrm{a}}$ & $0.88 \pm 0.14^{\mathrm{a}}$ & $0.72 \pm 0.10^{\mathrm{a}}$ \\
\hline HA & $0.97 \pm 0.01^{\mathrm{f}}$ & $0.70 \pm 0.06^{\mathrm{b}}$ & $1.04 \pm 0.02^{\mathrm{e}}$ & $0.26 \pm 0.01^{\mathrm{c}}$ & $0.35 \pm 0.12^{\mathrm{c}}$ & $0.33 \pm 0.01^{\mathrm{b}}$ \\
EA & $2.03 \pm 0.24^{\mathrm{b}}$ & $1.10 \pm 0.19^{\mathrm{ab}}$ & $2.64 \pm 0.01^{\mathrm{b}}$ & $0.21 \pm 0.03^{\mathrm{c}}$ & $0.44 \pm 0.03^{\mathrm{c}}$ & $0.15 \pm 0.04^{\mathrm{c}}$ \\
MA & $1.14 \pm 0.02^{\mathrm{dd}}$ & $0.75 \pm 0.03^{\mathrm{b}}$ & $1.62 \pm 0.08^{\mathrm{c}}$ & $0.34 \pm 0.04^{\mathrm{b}}$ & $0.67 \pm 0.06^{\mathrm{b}}$ & $0.20 \pm 0.15^{\mathrm{bc}}$ \\
\hline
\end{tabular}

${ }^{1)} \mathrm{HR}$, hot water extracts from Coffea Canephora; ER, 80\% ethanol extracts from Coffea Canephora; MR, 80\% methanol extracts from Coffea Canephora; HA, hot water extracts from Coffea Arabica; EA, $80 \%$ ethanol extracts from Coffea Arabica; MA, $80 \%$ methanol extracts from Coffea Arabica.

2)3-CQA, 3-caffeoylquinic acid; 4-CQA, 4-caffeoylquinic acid; 5-CQA, 5-caffeoylquinic acid, 4,5-diCQA, 4,5-dicaffeoylquinic acid; 3,4-diCQA, 3,4-dicaffeoylquinic acid; 3,5-diCQA, 3,5-dicaffeoylquinic acid.

${ }^{3)}$ Different superscripts within a column $(\mathrm{a}-\mathrm{e})$ indicate significant differences $(\mathrm{p}<0.05)$. 
(A)

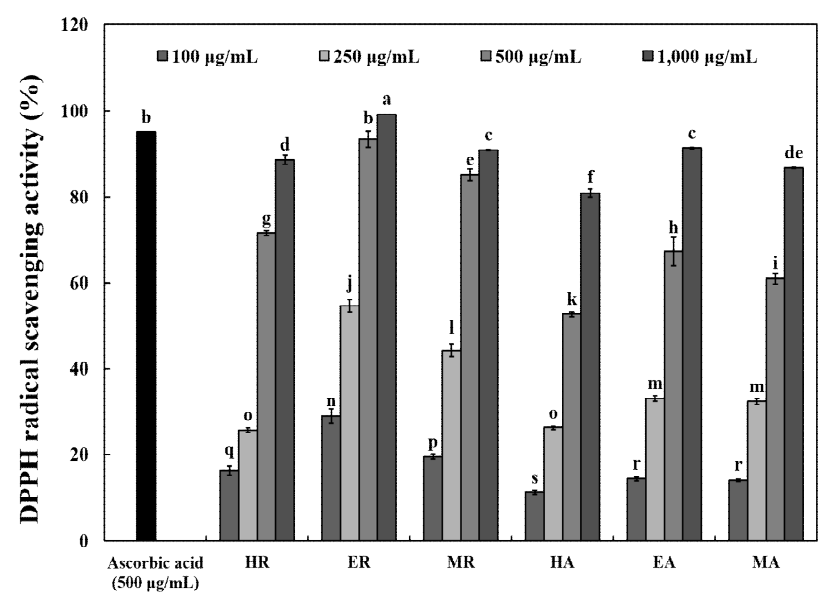

(B)

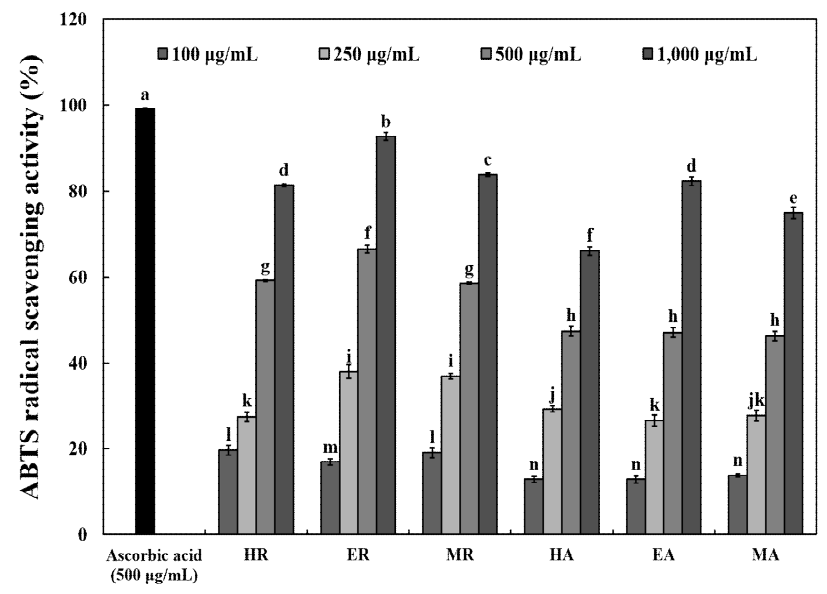

Fig. 2. DPPH (A) and ABTS (B) radical scavenging activity of green coffee bean extracts.

HR, hot water extracts from Coffea Canephora; ER, $80 \%$ ethanol extracts from Coffea Canephora; MR, $80 \%$ methanol extracts from Coffea Canephora; HA, hot water extracts from Coffea Arabica, EA, 80\% ethanol extracts from Coffea Arabica, MA, 80\% methanol extracts from Coffea Arabica.

Means \pm SD $(n=3)$ with different letters ( $a-s)$ above bars are significantly different by Duncan's multiple range test $(\mathrm{p}<0.05)$.

적으로 FRAP 활성이 증가됨을 확인하였으며, $80 \%$ 에탄올 추출물이 418.27-1,572.23 $\mu \mathrm{M}$ 로 나타나 다른 용매 추출물보 다 높은 활성을 나타내었다. 로부스타 및 아라비카 커피 생두 추출물이 $100-1,000 \quad \mu \mathrm{g} / \mathrm{mL}$ 농도에서 각각 321.91-1,572.23 $\mathrm{MM}, 291.61-1,470.40 \mu \mathrm{M}$ 로 나타나 로부스 타 커피 생두 추출물이 아라비카 커피 생두 추출물보다 우수한 FRAP 활성을

나타내었다. Kang 등(38)은 커피와 커피박 침출주의 FRAP 활성을 조사한 결과 $1,000 \mathrm{\mu g} / \mathrm{mL}$ 농도에서 1,743-1,851 $\mathrm{\mu M}$ 을 나타내 로부스타 및 아라비카 커피 생두 추출물보다 다소 높은 FRAP 활성을 나타내었다.

\section{산화적 손상에 대한 보호효과}

커피 생두 추출물을 폐 정상세포(L-132)에 농도별로 처
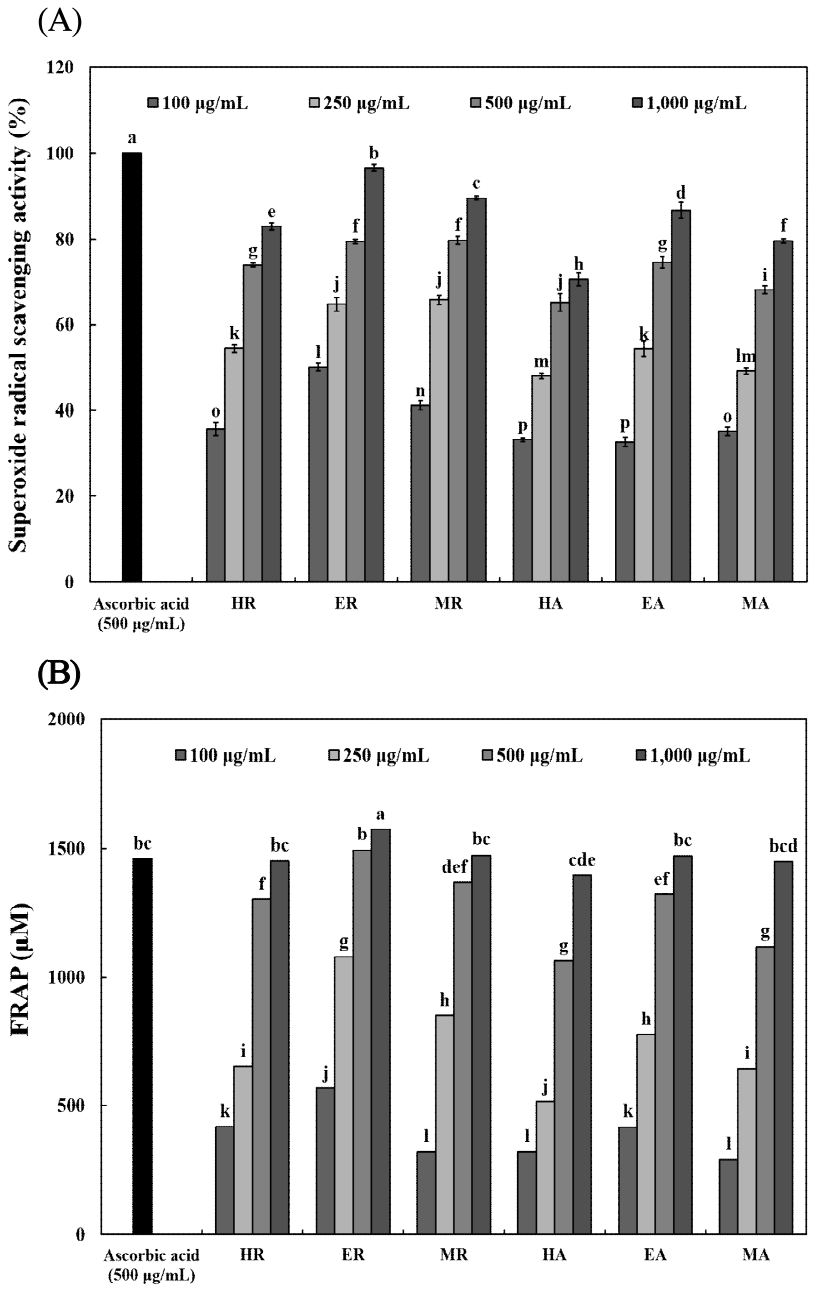

Fig. 3. Superoxide radical scavenging activity (A) and FRAP (ferric reducing antioxidant power) (B) of green coffee bean extracts.

HR, hot water extracts from Coffea Canephora; ER, $80 \%$ ethanol extracts from Coffea Canephora; MR, 80\% methanol extracts from Coffea Canephora, HA, hot water extracts from Coffea Arabica; EA, 80\% ethanol extracts from Coffea Arabica, MA, 80\% methanol extracts from Coffea Arabica.

Means \pm SD ( $\mathrm{n}=3$ ) with different letters (a-p) above bars are significantly different by Duncan's multiple range test $(\mathrm{p}<0.05)$

리하여 MTT assay 방법으로 세포 독성을 측정한 결과, 추출 물 100-1,000 $\mathrm{\mu g} / \mathrm{mL}$ 농도까지 유의적인 세포 사멸이 나타나 지 않아 세포 독성이 없음을 확인하였고(Fig. 4A), 100-1,000 $\mathrm{\mu g} / \mathrm{mL}$ 농도로 하여 L-132 세포의 세포보호 효과를 측정한 결과는 Fig. $4 \mathrm{~B}$ 와 같다. 인체 내 대사과정에서 생성되는 다양한 활성산소종은 흡연, 음주, 자외선 등의 외적 요인에 의해 생성될 수 있으며(39), 그 중 $\mathrm{H}_{2} \mathrm{O}_{2}$ 는 원형질막의 통과 가 쉬워 생리학적 및 병리학적 조건에서 산화적 손상을 주는 독성 물질로 이용되고 있다(40). 이러한 산화적 손상에 대한 커피 생두 추출물의 세포보호효과를 확인한 결과, 모 든 시료에서 $1 \mathrm{mM} \mathrm{H}_{2} \mathrm{O}_{2}$ 첨가구와 비교하여 활성이 유의적 으로 증가함을 확인하였다. 추출용매에 따른 커피 생두 추 출물의 세포보호효과는 $80 \%$ 에탄올 추출물이 78.14- 
$85.82 \%$ 로 다른 용매 추출물보다 높게 나타났으며, $80 \%$ 메 탄올 및 열수추출물 순으로 나타났다. 또한 로부스타 커피 생두 추출물은 $100-1,000 \mu \mathrm{g} / \mathrm{mL}$ 농도에서 $51.55-85.82 \%$ 로 나타나 아라비카 커피 생두 추출물보다 높은 세포보호효과 를 나타내었다. Anggreani와 Lee(41)의 연구에서 CGA는 활성산소종의 축적을 조절하고 세포 사멸에 관여하는 주요 단백질과 효소의 발현을 조절함으로써 자유라디칼에 의한 세포 사멸을 약화시킬 수 있다고 보고하였으며, Kwak 등 (42)은 산화적 손상에 의해 유도된 신경세포 독성에 대한 검정콩 추출물의 신경세포 보호효과를 확인한 결과, 500 $\mathrm{\mu g} / \mathrm{mL}$ 농도에서 $76.0 \%$ 의 생존률을 나타내 커피 생두 추출 물과 유사한 활성을 나타내었다.

(A)

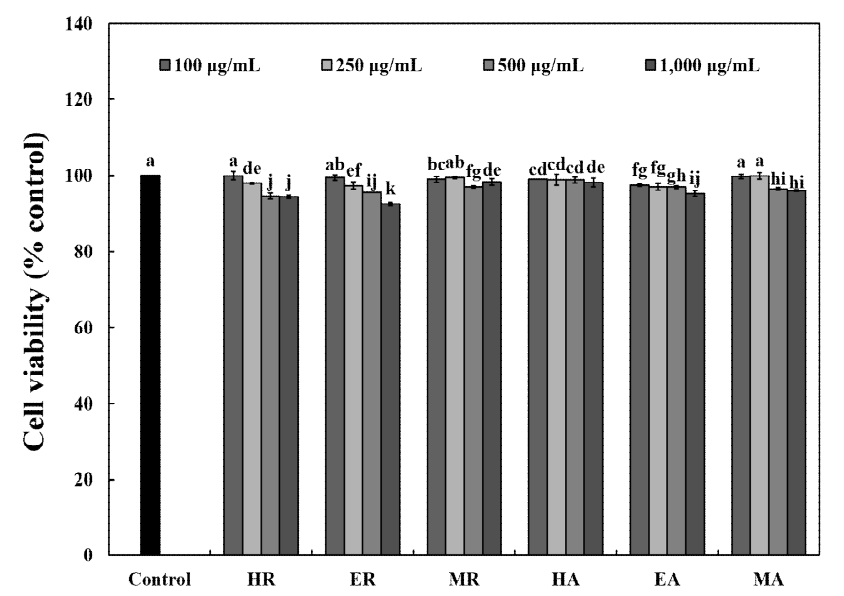

(B)

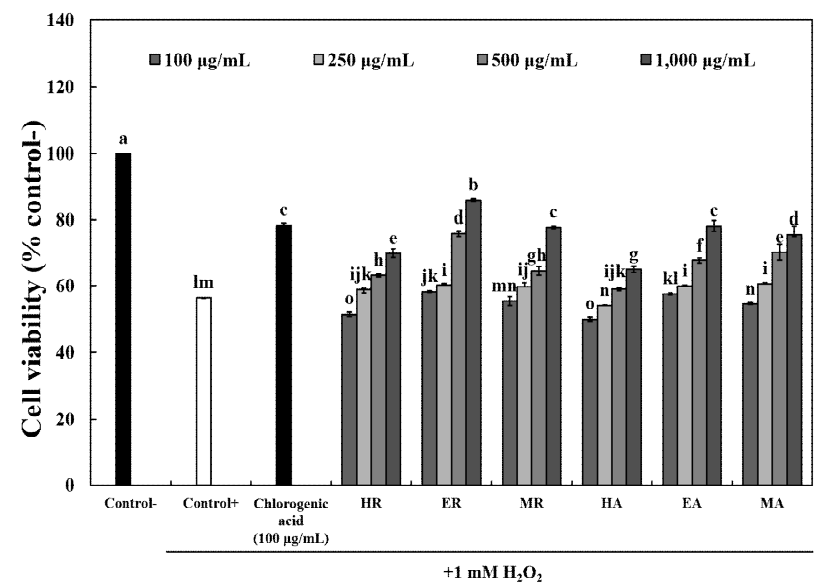

Fig. 4. MTT assay (A) and protective effects on cell viability against $\mathrm{H}_{2} \mathrm{O}_{2}(1 \mathrm{mM})$ induced oxidative damage (B) in L-132 cell line of green coffee bean extracts.

HR, hot water extracts from Coffea Canephora; ER, $80 \%$ ethanol extracts from Coffea Canephora; MR, $80 \%$ methanol extracts from Coffea Canephora; HA, hot water extracts from Coffea Arabica, EA, 80\% ethanol extracts from Coffea Arabica, MA, 80\% methanol extracts from Coffea Arabica.

Means \pm SD ( $n=3$ ) with different letters $(a-0)$ above bars are significantly different by Duncan's multiple range test $(\mathrm{p}<0.05)$.

\section{요 약}

본 연구에서는 커피 생두의 기능성 소재로서의 가치를 확인하고자 추출용매에 따른 커피 생두 추출물의 이화학적 품질특성 및 항산화 활성을 조사하였다. 추출용매에 따른 커피 생두 추출물의 수율은 $15.53-23 \%$ 이며, 총 당 및 가용성 단백질 함량은 아라비카 커피 생두 열수추출물 $(\mathrm{HA})$ 에서 각각 $58.45 \mathrm{~g} / 100 \mathrm{~g}$ 및 $23.04 \mathrm{~g} / 100 \mathrm{~g}$ 으로 나타났으며, 총 폴리페놀 및 총 플라보노이드 함량은 로부스타 커피 생두 $80 \%$ 에탄올 추출물(ER)에서 각각 $35.03 \mathrm{~g} / 100 \mathrm{~g}$ 및 12.14 $\mathrm{g} / 100 \mathrm{~g}$ 으로 가장 높은 함량을 나타내었다. Chlorogenic acid 함량은 로부스타 커피 생두 $80 \%$ 에탄올 추출물이 가장 많은 양을 함유하고 있었으며, 5-caffeoylquinic acid가 $1.04-3.18 \mathrm{~g} / 100 \mathrm{~g}$ 으로 커피 생두 chlorogenic acid의 주요 성분이었다. DPPH 및 $\mathrm{ABTS}$ radical 소거활성은 로부스타 커피 생두 $80 \%$ 에탄올 추출물이 $100-1,000 \mathrm{\mu g} / \mathrm{mL}$ 농도에서 16.51-99.17\% 및 12.85-92.61\%로 농도가 증가함에 따라 소 거활성이 증가하였으며, superoxide radical 소거활성 및 FRAP 활성 또한 로부스타 커피 생두 $80 \%$ 에탄올 추출물이 $100-1,000 \mu \mathrm{gg} / \mathrm{mL}$ 농도에서 35.79-96.47\% 및 321.91-1,572.23 $\mu \mathrm{M}$ 로 가장 우수한 활성을 나타내었다. 폐 정상세포인 L-132 세포에 커피 생두 추출물을 처리하여 세포 사멸에 대한 보호효과를 측정한 결과, 추출용매에 따른 커피 생두 추출물의 세포보호효과는 로부스타 커피 생두 추출물이 아라비카 커피 생두 추출물보다 높은 세포보호효과를 나타 내었으며, 특히 로부스타 커피 생두 $80 \%$ 에탄올 추출물에 서 $85.82 \%$ 로 세포 활성이 증가하여 우수한 세포보호효과를 나타내었다.

\section{감사의 글}

본 연구는 중소벤처기업부에서 지원하는 2017년도 산학 연협력기술개발사업(No.201800080001)의 연구수행으로 인한 결과물임을 밝힙니다.

\section{References}

1. Jennings PE, Barnett AH (1988) New approaches to the pathogenesis and treatment of diabetic microangiopathy. Diabetic Med, 5, 111-117

2. Fridovich I (1989) Superoxide dismutases: an adaption to paramagnetic gas. J Biol Chem, 264, 7761-7764

3. Seo YR (2014) A study on the development of functional beverage using mungbean. MS Thesis, Gachon University, Korea, p 13 
4. Kang RK, Min KS, Kang MH (2015) Physicochemical properties of supremo coffee according to grinding and brewing conditions. J Korean Soc Food Sci Nutr, 44, 89-96

5. Lee KS, Kim JM, Yoon KY (2017) Physicochemical properties, bioactive composition, and antioxidant activity of different coffee beans dependent on the cultivation region. Korean J Food Sci Technol, 49, 474-479

6. Kim HK, Hwang SY, Yoon SB, Chun DS, Kong SK, Kang KO (2007) A study of the characteristics of different coffee beans by roasting and extracting condition. J Korean Soc Food Sci Nutr, 20, 14-19

7. Jo SJ, In MJ, Kim DC (2016) Effect of the roasting intensity and extraction time of coffee bean on the antioxidant activity of coffee extract. Food Eng Prog, 20, 165-169

8. Kim TS, Yang WS, Park SI, Lee SP, Kang MH, Lee JH, Park IB, Park HJ, Murai H, Okada T (2012) Effect of green coffee bean extract supplementation on body fat reduction in mildly obese women. Korean $\mathbf{J}$ Food Culture, 27, 407-413

9. Gi KH (1988) This study is on the analysis of the aroma compounds and compare the result with sensory evaluation score by roasting time. MS Thesis, Hanyang University, Korea, p 1-34

10. Baik HJ (1986) Headspace gas chromatographic analysis and sensory evaluation of various domestic and foreign-made commercial roasted and ground coffee. MS Thesis, Hanyang University, Korea, p 1-46

11. Clark RJ (1985) Coffee chemistry. Elsevier Applied Science Publishers, Barking, UK, p 115-143

12. Sivetz M, Desrosier NW (1979) Coffee technology. AVI Publishing Co Inc, Westport, CT, USA, p 467

13. Lee JH, Byun SY (2008) Enrichment of coffee flavors with supercritical carbon dioxide. Korean J Biotechnol Bioeng, 23, 193-198

14. Kim JY, Han YS (2009) Influence of roasting time on antibacterial and antioxidative effects of coffee extract. Korean J Food Cookery Sci, 25, 496-505

15. Saha SK, Brewer CF (1994) Determination of the concentrations of oligosaccharides, complex type carbohydrates, and glycoproteins using the phenolsulfuric acid method. Carbohydr Res, 254, 157-167

16. Lowry OH, Rosebrough NJ, Farr AL, Randall RJ (1951) Protein measurement with the folin phenol reagent. J Biol Chem, 193, 265-275
17. Singleton VL, Rossi JA (1965) Colorimetry of total phenolics with phosphomolybdic-phosphotungstic acid reagents. AM J Enol Viticlt, 16, 144-158

18. Zhishen J, Mengcheng T, Jianming W (1999) The determination of flavonoid contents in mulberry and their scavenging effects on superoxide radicals. Food Chem, 64, 555-559

19. Blois MS (1958) Antioxidant determinations by the use of a stable free radical. Nature, 181, 1199-1200

20. Re R, Pellegrini N, Proteggente A, Pannala A, Yang M, Rice-Evans C (1999) Antioxidant activity applying an improved ABTS radical cation decolorization assay. Free Radic Biol Med, 26, 1231-1237

21. Nishikimi M, Rao NA, Yagi K (1972) The occurrence of superoxide anion in the reaction of reduced phenazine methosulfate and molecular oxygen. Biochem Biophys Res Commun, 46, 849-854

22. Benzie IFF, Strain JJ (1996) The ferric reducing ability of plasma (FRAP) as a measure of "antioxidant power" the FRAP assay. Anal Biochem, 239, 70-76

23. Hwang EG (2003) Protective effects of a-tocopherol and captopril against hydrogen peroxide-induced apoptosis on human lug epithelial cell line L-132. Ph D Thesis, Kyunghee University, Korea, p 1-32

24. Han JH, Moon HK, Chung SK, Kang WW (2013) Comparison of antioxidant activities of Radish Bud (Raphanus sativus L) according to extraction solvents and sprouting period. J Korean Soc Food Sci Nutr, 42, 1767-1775

25. Kwon YS, Jeon IS, Hwang JH, Lim DM, Kang YS, Chung HJ (2009) Biological activities of maca (Lepidium meyenii) extracts. J Korean Soc Food Sci Nutr, 38, 817-823

26. Kim HS (1994) A study on the phytate content and protein digestibility of various soy products. MS Thesis, Ewha Womans University, Korea, p 1-63

27. Voya J, Belinky PA, Aviram M (1997) Antioxidant constituents from licorice roots: Isolation, structure elucidation and antioxidative capacity toward LDL oxidation. Free Radic Biol Med, 23, 302-313

28. Cho IS, Hong MS, Lee ES, Kim SJ, Lee YC, Kim SD, Jo HB, Kim JH, Jung K (2015) Study of the characteristics of roasted coffee bean in seoul. J Food Hyg Saf, 30, 236-241

29. Park HM, Hong JH (2014) Effect of extraction methods on antioxidant activities of Mori ramulus. J Korean Soc Food Sci Nutr, 43, 1709-1715 
30. Clifford MN, Wight J (1976) The measurement of feruloylquinic acids and caffeoylquinic acids in coffee beans. J Sci Food Agric, 27, 73-84

31. Kim KJ, Park SK (2006) Changes in major chemical constituents of green coffee beans during the roasting. Korean J Food Sci Technol, 38, 153-158

32. Fujioka K, Shibamoto T (2008) Chlorogenic acid and caffeine contents in various commercial brewed coffees. Food Chem, 106, 217-221

3Farah A, Donangelo CM (2006) Phenolic compounds in coffee. Braz J Plant Physiol, 18, 23-36

34. Park JB (2013) Isolation and quantification of major chlorogenic acids in three major instant coffee brands and their potential effects on $\mathrm{H}_{2} \mathrm{O}_{2}$-induced mitochondrial membrane depolarization and apoptosis in PC-12 cells. Food Funct, 4, 1632-1638

35. Kim JY (2008) Food materialization of spent coffee ground extracts and variation of coffee antioxidant ability according to extraction process. MS Thesis, Pukyong National University, Korea, p 1-61

36. Woo SW (2016) Antioxidant activity, nutrients and caffeine analysis of fermented coffee. MS Thesis, Daegu Haany University, Korea, p 1-69

37. Lee JW, Shin HS (1996) Physicochemical properties of antioxidant fractions extracted from freeze-dried coffee by various solvents. Korean J Food Sci Technol, 28, 109-116

38. Kang JE, Park SK, Guo TJ, Kang JY, Lee DS, Kim JM, Kwon OJ, Lee U, Heo HJ (2016) Antioxidant activity and comparative analysis of major functional compounds in liqueur using coffee and coffee-ground. Korean J Food Preserv, 23, 560-567

39. Ha JS, Park SK, Park CH, Seung TW, Guo TJ, Kang JY, Lee DS, Kim JM, Lee U, Heo HJ (2015) Neuronal cell protective effect of new green extract against $\mathrm{H}_{2} \mathrm{O}_{2}$-induced oxidative stress and analysis of bioactive compounds. Korean J Food Sci Technol, 47, 673-679

40. Kim, MJ, Lee SB, Choi, JH, Kwon SH, Kim HD, Bang MH, Yang SA (2013) Characteristics of fermented dropwort extract and vinegar using fermented dropwort extract and its protective effects on oxidative damage in rat glioma C6 cells. Korean J Food Sci Technol, 45, 350-355

41. Anggreani E, Lee CY (2017) Neuroprotective effect of chlorogenic acids against alzheimer's disease. Int J Food Sci Nutr Diet, 6, 330-337

42. Kwak JH, Jo YN, Jeong JH, Kim HJ, Jin SI, Choi SG, Heo HJ (2013) Protective effects of black soybean seed coat Extracts against oxidative stress-induced neurotoxicity. Korean J Food Sci Technol, 45, 257-261 